\title{
UNIVERSIDADES PÚBLICAS AGONIZAM PELA FALTA DE RECURSOS
}

Coluna publicada em 19.9.2017: <https://www.conjur.com.br/2017-set-19/ contas-vista-universidades-publicas-agonizam-falta-recursos $>$

A crise financeira que assola o país está se assemelhando a um verdadeiro "furacão" que não para de produzir vítimas. E mostra como a má gestão pode produzir resultados muito piores do que desastres naturais de grandes proporções. Enquanto "Irma" destelhou casas, causou danos materiais e até mortes, por aqui alguns anos de administrações que foram um verdadeiro desastre, e nada natural, provocaram a destruição de nossas universidades públicas que levaram décadas para serem construídas.

Nas últimas semanas chamou especial atenção o caso da Universidade Estadual do Rio de Janeiro - UERJ, que está "agonizante", asfixiada por falta de recursos, tendo recebido até uma "extrema unção" do governo federal, que insinuou deva ser extinta. ${ }^{1}$

Mas não é a única. A Universidade de São Paulo - USP já teve o auge de sua crise há pouco tempo, e ainda sofre com o orçamento apertado. As universidades federais também estão em colapso. A Universidade Federal de Sergipe - UFS ameaçou suspender as atividades, a Universidade de Brasília - UnB anunciou um déficit acumulado de $\mathrm{R} \$ 10$ milhões de reais no ano e o desligamento de funcionários terceirizados, a Universidade Federal de Santa Maria - UFSM demitiu funcionários e suspendeu obras em andamento e a Universidade Federal do Rio de Janeiro

1 O Parecer Conjunto 1/2017/CORFI/COREM/COPEM/COAFI/COINT/SURIN/STN/ MF-DF propõe a extinção de mais empresas públicas e revisão do papel do Estado, e entre as medidas de ajuste sugere "a revisão da oferta de ensino superior" (Parecer do Ministério da Fazenda sugere o fim da UERJ. Jornal do Brasil, 5 de setembro de 2017; Tesouro sugere "revisão da oferta” de universidades públicas do Rio. Portal UOL, 5 de setembro de 2017). 
- UFRJ ameaça suspender os pagamentos das bolsas de iniciação científica. ${ }^{2}$ Um cenário desolador, como registra Sabina Righetti em percuciente análise do tema. ${ }^{3}$ Em resumo, a crise financeira instalou o caos no ensino público superior. E uma crise que não escolhe ente federado, haja vista que abrange várias universidades federais e também estaduais.

A questão do financiamento das universidades é bastante interessante sob o ponto de vista do Direito Financeiro, e há várias questões que merecem abordagem e melhor reflexão.

Nosso federalismo cooperativo fica bem evidente no âmbito da educação, em que a Constituição distribui as receitas e encargos entre os entes federados, estabelecendo um regime de cooperação para a prestação desse serviço público fundamental para o desenvolvimento do país. E onde se vê uma distribuição que procura respeitar critérios de eficiência alocativa, deixando a cada ente federado a responsabilidade para atender a necessidade em matéria educacional que melhor se ajusta às suas características. É o que justifica a atribuição prioritária aos municípios da responsabilidade pelo ensino fundamental e educação infantil (CF, art. 211, b), onde a mobilidade do usuário é baixa. Já no ensino superior, em que o usuário tem facilidade de locomoção, os níveis mais próximos do governo central mostram-se mais adequados sob o ponto de vista federativo, evitando as distorções do "efeito-carona" (free-rider effect). ${ }^{4}$

Daí por que a maior parte das universidades públicas integra a administração pública federal, e apenas alguns Estados financiam o ensino público superior, mantendo universidades próprias.

Nossa Constituição dá especial destaque ao ensino superior e às universidades, assegurando-lhes "autonomia didático-científica, administrativa e de gestão financeira e patrimonial” (art. 207, caput). A autonomia financeira de órgãos que integram o ente federado, à semelhança dos poderes, ainda que fixada constitucionalmente, é sempre relativa, até porque a capacidade arrecadatória de que dispõem

2 Acabou o dinheiro: universidades públicas estão perto do colapso, por Gabriel Castro, Gazeta do Povo, 8 de agosto de 2017.

3 RIGHETTI, Sabine. Crise nas universidades, Ciência e Cultura, vol. 69, n. 2, São Paulo, abr./jun. 2017.

4 Falei sobre o tema em $\mathrm{O}$ orçamento público e o financiamento da educação no Brasil. In: HORVATH, Estevão; CONTI, José Mauricio; SCAFF, Fernando F. (Org.). Direito Financeiro, Econômico e Tributário. Homenagem a Regis Fernandes de Oliveira. São Paulo: Quartier Latin, 2014. p. 481-496. 
é muito pequena, insuficiente para fazer frente às vultosas despesas nas quais incorrem, como as relativas ao pagamento de pessoal.

Sendo assim, a regra é dependerem de dotações orçamentárias, com recursos oriundos essencialmente do sistema próprio de arrecadação do ente federado, e que se soma a outras fontes de naturezas diversas, como as arrecadações próprias, transferências, contratos, doações e outros. E são valores expressivos.

No âmbito federal, há inclusive um volume do anexo da lei orçamentária de 2017 (vol. V) especificamente destinado a detalhar as despesas do Ministério da Educação, que congrega as instituições de ensino superior federais. Prevê para este exercício de 2017 um montante superior a 100 bilhóes de reais ( $\mathrm{R} \$$ 107.517.408.946,00), distribuído entre dezenas de universidades, institutos, fundações e hospitais. ${ }^{5}$

Nos Estados que mantêm instituições de ensino público superior, a situação não é diferente. Em São Paulo, destacam-se as três universidades públicas estaduais: USP (Universidade de São Paulo), Unicamp (Universidade Estadual de Campinas) e Unesp (Universidade Estadual Júlio de Mesquita Filho), cujas dotações orçamentárias para o exercício financeiro de 2017 são, respectivamente, $\mathrm{R} \$$ 5.052.466.860,00, $\mathrm{R} \$ 2.711 .717 .611,00$ e $\mathrm{R} \$$ 2.497.059.952,00, perfazendo um total, para as três universidades, superior a 10 bilhōes de reais. A UERJ foi contemplada com dotação orçamentária superior a 1 bilhão de reais para o exercício financeiro de 2017.6

Alguns instrumentos importantes para assegurar a autonomia financeira das universidades públicas podem ser encontrados, como nos Estados acima citados, e colaboram para torná-las mais independentes sob o ponto de vista da gestão financeira, o que, como se pode constatar, parece não ter sido suficiente para evitar as crises pelas quais têm passado.

No Estado de São Paulo criou-se um compromisso político de se destinar às três universidades estaduais um porcentual $(9,57 \%)$ da arrecadação do ICMS, o que se materializa juridicamente pela inserção de tal determinação nas leis de diretrizes orçamentárias, que se renovam anualmente, criando o que André Carvalho denomina "vinculação simbólico-institucional".

5 Lei Orçamentária Federal de 2017 (Lei 13.414, de 10 de janeiro de 2017, vol. V).

6 R\$ 1.113.007.786,00, cf. Lei Estadual-RJ n. 7574, de 17 de janeiro de 2017, vol. II, p. 370, Unidade orçamentária 4043 - Fundação Universidade do Estado do Rio de Janeiro.

7 CARVALHO, André Castro. Vinculação de receitas públicas. São Paulo: Quartier Latin, 2010. p. 43. 
O Rio de Janeiro optou por dar uma garantia constitucional à UERJ, fazendo constar de sua Constituição a destinação do porcentual mínimo de $6 \%$ da receita tributária líquida. $^{8}$

No entanto, apesar de todas essas garantias, vê-se que não se conseguiu evitar esse colapso financeiro. Disso é importante extrair algumas lições. Uma delas é de que as vinculaçōes (entendidas em seu significado "lato sensu", abrangendo aquelas que importam na destinação de receitas específicas a determinados gastos, as despesas mínimas obrigatórias e outros instrumentos do gênero) não são uma panaceia para os problemas financeiros. ${ }^{9}$ Nos casos citados em que elas estavam presentes, vê-se que o fato de a recessão econômica provocar a redução das receitas tributárias (hipótese do Rio de Janeiro) e do ICMS (no caso de São Paulo) fez com que houvesse uma queda nos recursos destinados às universidades públicas, e estas, sem margem para reduzir suas despesas, viram-se diante de uma situação de insustentabilidade financeira difícil de reverter. Outra lição é que as universidades padecem da falta de gestores preparados, como ressaltou José Matias-Pereira, professor de finanças públicas da UnB, que considerava esse colapso uma "tragédia anunciada". ${ }^{10}$ Aperfeiçoamentos na gestão dos recursos públicos são cada vez mais necessários em toda a administração pública, e na área da educação a situação não é diferente. ${ }^{11}$ Em se tratando de áreas prioritárias como a educação, as vinculações são mais do que bem-vindas, e colaboram para evitar que gestores despreparados reduzam os recursos que deveriam lhe ser destinados, realocando-os para setores menos relevantes. Mas não podem ser mal aplicados, especialmente em épocas de crise financeira, em que os recursos ficam cada vez mais escassos, e portanto mais valiosos.

Há muitos hospitais universitários entre as unidades orçamentárias que integram o ensino superior do Brasil hoje. Agora que as universidades públicas estão verdadeiramente na UTI, é hora de elas mostrarem sua utilidade, antes que nos próximos orçamentos passemos a encontrar funerárias no orçamento da educação...

8 Art. 309, $\$ 1^{\circ}$ : O poder público destinará anualmente à Universidade do Estado do Rio de Janeiro - UERJ, dotação definida de acordo com a lei orçamentária estadual nunca inferior a $6 \%$ da receita tributária líquida, que lhe será transferida em duodécimos, mensalmente.

9 Como já foi abordado em Vinculaçôes orçamentárias não são a panaceia dos problemas, nesta edição, p. 207-210.

10 Acabou o dinheiro: universidades públicas estão perto do colapso, texto já citado anteriormente.

11 Ver Nem só com royalties se melhora qualidade da educação, nesta edição, p. 55-58. 